\title{
Use of Dried Blood Spot to Improve the Diagnosis and Management of HIV in Resource-Limited Settings
}

\author{
Chatté Adawaye $^{1 *}$, Erick Kamangu ${ }^{2}$, Ali Mahamat Moussa ${ }^{3}$, Bertin Tchoumbou ${ }^{3}$, Dolores Vaira ${ }^{4}$, \\ Michel Moutschen ${ }^{5}$
}

${ }^{1}$ Institute of Science and Technology of Abeche, Abeche, Chad; ${ }^{2}$ Department of Basic Sciences, Faculty of Medicine, University of Kinshasa, Kinshasa, DRC; ${ }^{3}$ Faculty of Medicine, Universty of Ndjamena, General Hospital of Ndjamena, Ndjamena, Chad; ${ }^{4}$ Laboratoire de Référence SIDA, CHU de Liège, Liège, Belgium; ${ }^{5}$ Service of Infectious Diseases and General Internal Medicine, University Hospital of Liège, Liège, Belgium.

Email: *adawayechatte@gmail.com

Received June $25^{\text {th }}, 2013$; revised July $25^{\text {th }}, 2013$; accepted August $16^{\text {th }}, 2013$

Copyright (C) 2013 Chatté Adawaye et al. This is an open access article distributed under the Creative Commons Attribution License, which permits unrestricted use, distribution, and reproduction in any medium, provided the original work is properly cited.

\begin{abstract}
Over $75 \%$ of people infected with HIV live in countries where health resources are very limited for the diagnosis and biological monitoring of people infected by the virus. In resource-limited settings, the use of DBS is a valuable alternative. It has provided technical and economical alternative to the collection of blood in the tubes for testing HIV infection. The DBS can be kept for over a year, it is economical in storage space and facilitates storage conditions because it can be stored at room temperature. It is more discreet and easier to carry over liquid samples that require tubes and other appropriate materials. The amount is sufficient for certain analyses of DNA generally, but may be insufficient for the analysis of viral RNA if the viral load is low. Its disadvantage is often associated with small amounts of blood collected available for testing, and the difficulties encountered in laboratories to extract the maximum possibilities without material contamination. DBS can be stored at room temperature $\left(25^{\circ} \mathrm{C}-35^{\circ} \mathrm{C}\right)$, at $4^{\circ} \mathrm{C},-20^{\circ} \mathrm{C}$ or even $-70^{\circ} \mathrm{C}$. With PCR, the DBS is a suitable medium for the diagnosis of patients infected with HIV, virological monitoring by the VL and even analyzing viral genotype. It is a handy stand for the collection, transport and analyses of biological monitoring of HIV infection. It is indeed very suitable for environments with limited accessibility where it is difficult for specialized laboratories to monitor these patients. The DBS is suitable for resource-limited settings.
\end{abstract}

Keywords: DBS; HIV; Resources Limited Setting; Viral Load; Genotyping

\section{Introduction of DBS in Biological Monitoring of HIV Infection}

It has been estimated that over 34 million people infected with HIV in 2012 [1]. Over $75 \%$ of these people live in countries where health resources are very limited for the diagnosis and biological monitoring of victims [1]. Hospitals and laboratories are, for the most part, limited and under-equipped to overcome the problem of diagnosis and monitoring of HIV infection. Logistical difficulties such as transport of blood samples and respect for the cold chain make it difficult to monitor patients who live far from specialized centers.

The diagnosis of HIV infection is often limited for Rapid Diagnostic Tests (RDTs) to monitor HIV-infected patients with biochemical, serological and $\mathrm{CD} 4 / \mathrm{CD} 8$ to

${ }^{*}$ Corresponding author. infection [2]. PCR standard diagnostic tool and biological monitoring of HIV infection are hardly accessible even in large hospitals [1,3]. Cost, lack of qualified staffs and a proper system maintenance staff, unstable power supply systems, transport and storage of samples are some parameters that make its handling difficult in some areas.

Although WHO has recommended the use of clinical monitoring and counting of CD4 lymphocytes for resource-limited settings, several studies have demonstrated that monitoring underestimated the impact of virological failure [4-6]. Therefore patients are at risk of poor monitoring and miss-treatment. It was therefore recommended to explore the feasibility of viral load (VL) in these environments.

Used for over 50 years [7], the Dried Blood Spot (DBS) or blotting paper remains a technical and economical al- 
ternative to the collection of blood in the tubes for testing for HIV infection. The method of collecting blood from veins in the tubes is difficult to manage in resourcelimited settings. Sampling, sample storage are in good conditions $\left(2^{\circ} \mathrm{C}-8^{\circ} \mathrm{C}\right)$ to avoid losses, transport samples in the time and in the right conditions (respect for the cold chain) to the center or specialized laboratory, so that these samples are processes. With the PCR technic, samples are to be taken care of very quickly to limit losses of the nucleic acid. The DBS technique allows sending the collected samples easily to specialized laboratories limiting constraints of storage and transportation condition. DBS can be prepared from any environment in accordance with good laboratory standards (Good Laboratory Practice-GLP) and sent even by local postal services.

\section{Advantages}

DBS can be kept in its original state for several years. It is less invasive, economical storage space and facilitates storage conditions because it can be stored at room temperature. It also makes it easy to collect drops of blood from a finger prick or heel of infants in the maternity ward or in remote areas with limited accessibility.

It requires a small amount of blood, it is more discreet and easier to carry over liquid samples that require tubes and other appropriate materials [8]. Its delivery in specialized, local or international laboratories for diagnostic analysis or research is easier and faster [9]. Samples can be sent out by mail in a sealed box without worrying about losing the quality of the sample. It is less invasive in the length of its use, the sample for analysis. It is also less expensive compared to the collection of liquid blood in tubes, tube prices and staff for collection. Contamination risks to health personnel are also reduced with the use of DBS [10]. The small amount, ease of sample collection in hospital and non-hospital, ease of storage and transport of samples and low cost make that this method of collection is ideal for resource-limited settings [1012].

Although the amount is limited, the quality of genetic material that is extracted from the DBS is comparable to that extracted from whole blood and/or its derivatives. So far, several protocols have been adapted for the extraction of genetic material from the DBS. These are specific protocols for extraction of DNA and RNA.

To optimize the performance of the extraction of RNA, it was developed two variants of DBS: The Dried Spot Serum (DSS) [13-16] and Dried Plasma Spot (DPS) [15-21]. With these variants, whole blood is first centrifuged and only serum or plasma is then deposited on the substrate, this limits the presence of DNA in the RNA sample. These techniques are used for the amplification of RNA in order to check for a viral load or genotype
[13-21]. Some studies have shown that the performance of the DBS can be optimized in the laboratory from whole blood in the tube.

\section{Limits}

Blood samples are collected on the DBS of the order of 50 to $100 \mu \mathrm{l}$ of blood (or plasma) or 1 to 2 drops per spot. This is enough for some analysis on DNA in general $[16,22]$, but may be insufficient for the analysis of viral RNA if the viral load is low, less than 1000 copies $/ \mathrm{mL}$ or a of $3.0 \mathrm{log}$ viral load [12-53]. The disadvantage of DBS is often associated with small amounts of blood collected available for testing, and the difficulties encountered in laboratories in order to extract the maximum possible material without contamination $[12,16]$. Indeed, the extraction of DNA and RNA on DBS protocols are more laborious and longer than the extraction of blood (or its derivatives) liquids $[12,16]$, it is for most protocols modified to optimize the performance results of this support. The quality of the filter paper used also plays an important role in the collection of samples $[10,23]$.

\section{Storage Conditions}

DBS can be stored at room temperature $\left(25^{\circ} \mathrm{C}-35^{\circ} \mathrm{C}\right)$ in a refrigerator at $4^{\circ} \mathrm{C}$ in a freezer at $-20^{\circ} \mathrm{C}$ or even in a freezer at $-70^{\circ} \mathrm{C}$. After collection of the samples, DBS must be properly dried and packaged to prevent contamination, and placed in a safe place for its preservation. It is recommended to leave the DBS to dry for a little more than 1 hour (1 to 12 hours of drying) at room temperature before storing. One study showed a longer drying (18 - 24 hours) away from light does not affect the quality of the final performance of the sample [12,24].

DBS stored at room temperature can remain stable for optimum performance up to an average of 14 days (2 weeks) before starting to lose the quality of material that are deposited [12,16,25]. Bertagnolio et al., and Wallis et al. reported a good $(90 \%)$ amplification efficiency after storage for 3 months at ambient temperature with a humidity of $85 \%[12,16,26,27]$, and Ziemniak et al. have published comparable performance on DBS stored at room temperature for about 5 months for genotyping [12, 28]. Nelson et al. found a yield of $69 \%$ and a decrease of $\log 10$ viral load with DBS stored at room temperature for 3 to 6 years $[12,29]$. At $4^{\circ} \mathrm{C}$, it retains up to 12 months without loss of performance $[12,27,30]$. In a freezer $\left(-20^{\circ} \mathrm{C}\right)$ or a deep-freezer $\left(-70^{\circ} \mathrm{C}\right)$, it will keep for several years while maintaining a similar during the initial sampling [12,16,31] quality. This material sample collection is relatively stable in these conditions. The ideal storage temperature therefore depends on the use to which the equipment is intended over time.

Storage in extreme conditions (above $37^{\circ} \mathrm{C}$ with $100 \%$ 
humidity) causes a significant decrease in the quality of genetic material more prolonged exposure, the quality decline [32]. Exposure in these conditions over 2 weeks significantly decrease the quality and quantity of extracted DNA, and make it difficult to extract RNA [27,32].

\section{DBS, Diagnosis and Viral Load}

By qualitative or quantitative PCR, several research teams have shown that DBS and its variants (DPS and DSS), are suitable materials for the diagnosis of patients with HIV infection and virological monitoring [12,16]. It is even recommended by WHO for the early diagnosis of children born to HIV-positive mothers in the world, but especially in Africa where the rate of vertical transmission is not very well controlled [12]. It has been proven for monitoring HIV patients in resources limited settings in different countries $[8,9,11,12,17,24,27,33-42]$.

For the diagnosis of HIV-1 qualitative PCR, the sensitivity of DBS is $100 \%$ when stored according to good standards $[12,16]$. Detection by qualitative PCR on RNA or proviral DNA gave identical to those obtained from whole blood, buffy coat, serum or plasma results even when stored under ideal conditions. With less than 1000 copies $/ \mathrm{ml}$ of viral load, qualitative PCR on RNA DBS loses its sensitivity $(58 \%-80 \%)$ depending on the techniques used [12,16,22,26,28,31,43].

For Viral Load, the sensitivity and specificity of this support are more than $98 \%$ for greater than 5000 copies per milliliter loads. Between 1000 and 4000 copies $/ \mathrm{ml}$, the sensitivity of quantification is lost, it varies between $80 \%$ and $98 \%$ if the storage conditions are ideal. For less than 1000 copies $/ \mathrm{ml}$ of viral load, the sensitivity is $58 \%$ to $80 \%$ for matches with the plasma $[12,16,22,24,26,28$, $31,38,43-47]$.

It is therefore an essential tool for the diagnosis of HIV infection and monitoring of patients with greater than 1000 copies $/ \mathrm{ml}$, provided they meet the conditions of storage for viral load tools.

DBS has also been used in serology for p24 antigen and for the enumeration of CD4 T-cells [2,48]. Blood components are not affected by the paper and drying although it is fragile and heat.

\section{DBS and Genotyping}

Recently, DBS was evaluated for genotyping tests. The results were very convincing with correlation coefficient of amplification of more than $90 \%$ using samples of various origins $[12,16,22,26,28,30,31,36,43,49-53]$. Several kits sequencing were used to confirm its use for genotyping with great success in more than $80 \%$ success rate.

All studies reported a high correlation between the changes in resistance of the material collected in the plasma and that the DBS, with a nucleotide correlation up to
$99.95 \%[12,16,22,26,28,30,31,36,43,49]$. As for the quantitative PCR, the efficiency of amplification for genotyping down with samples that have less than 1000 copies/ $\mathrm{ml}$ of viral load $[12,16,22,26,30,31,43]$. But this decrease does not affect the quality of material that can be extracted $[12,16,22,26,30,31,43]$.

There is potential interference of proviral DNA and viral RNA during genotypic [12,16,22,28,31]. Some mutations archived in proviral DNA can alter the pattern of results in the analysis for mutations in the initiation of treatment or during sero-surveillance $[12,22,28,31]$. This is why some teams have developed the use of DSS or DPS for genotyping of RNA [13,15,17]. There is less possibility of finding DNA with DSS or DPS.

For genotyping, genetic material is better preserved on the DBS when stored at $4^{\circ} \mathrm{C}[30]$. It is possible to find the same consistency from genetic material extracted one year after removal of the medium kept at $4^{\circ} \mathrm{C}$.

\section{Conclusion}

DBS is a handy material for the collection, transport and analyses of biological monitoring of HIV infection. It reduces the amount of blood required per sample for patients. It is less invasive and easier to carry. It is easy to keep under ambient conditions. It has been tested under different conditions and gives results consistent surprising. DBS can be used for the diagnosis of HIV, to assess the viral load, CD4 T-cells counts, and even for genotyping and monitoring of resistance. It is indeed very suitable for environments with limited accessibility, where it is difficult for specialized laboratories to monitor these patients. DBS is suitable for resource-limited settings.

\section{REFERENCES}

[1] ONUSIDA-Organisation Mondiale de la Santé, "Rapport des données épidémiologiques," 2012. www.unaids.org

[2] J. W. Mellors, A. Munoz, J. V. Giorgi, J. B. Margolick, C. J. Tassoni, et al., "Plasma Viral Load and CD4+ Lymphocytes as Marker of HIV-1 Infection," Annals of Internal Medicine, Vol. 126, No. 12, 1997, pp. 946-954. doi:10.7326/0003-4819-126-12-199706150-00003

[3] A. Ammann and S. Burrowers, "Early Diagnosis of HIV Infection in HIV-Exposed Infants: Can Complexity and Cost Be Overcome in Resource-poor Settings? Women, Children, and HIV. Resources for Prevention and Treatment," 2007. www.womenchildrenhiv.org

[4] B. Ledergerber, J. D. Lundgren and A. S. Walker, "Predictors of Trend in CD4-Positive T-Cell Count and Mortality among HIV-1-Infected Individuals with Virological Failure to All Three Antiretroviral-Drug Classes," Lancet, Vol. 364, No. 9428, 2004, pp. 51-62. doi:10.1016/S0140-6736(04)16589-6

[5] A. Bahrani, R. Ramaswamy and E. C. Oldfield, "Effects of Virologic Rebound on CD4 Cell Counts," Medicine 
Clinical Infectious Diseases, Vol. 32, No. 8, pp. 12311232. doi: $10.1086 / 319755$

[6] N. E. Kamangu, M. E. Kawila, H. Mukumbi and L. G. Mvumbi, "Estimated Rates of Treatment Failure in FirstLine Antiretroviral Treatment in Kinshasa: Case of ACSAMO-Congo," IJCRIMPH, Vol. 4, No. 6, 2012, pp. 885891.

[7] J. V. Mei, J. R. Alenxander, B. W. Adam and W. H. Hannon, "Use of Filter Paper for Collection and Analysis of Human Whole Blood Specimens," Journal of Nutrition, Vol. 131, 2001, pp. 1631S-1636S.

[8] A. Johannessen, C. Garrido, N. Zahonero, L. Sandvik, E. Naman, S. L. Kivuyo, et al., "Dried Blood Spots Perform Well in Viral Load Monitoring of Patients Who Received Antiretroviral Treatment in Rural Tanzania," Medicine Clinical Infectious Diseases, Vol. 49, No. 6, 2009, pp. 976-981. doi:10.1086/605502

[9] L. C. Ivers, M. C. Smith Fawzi, J. Mann, J. G Jerome, M. Raymonville and J. S. Mukherjee, "Overseas Processing of Dried Blood Spots for Timely Diagnosis of HIV in Haitian Infants," The Pan American Journal of Public Health, Vol. 24, No. 5, 2008, pp. 331-335. doi:10.1590/S1020-49892008001100005

[10] D. Anitha, P. Sumathi and S. MiniJacob, "Comparative of Venous Liquid Blood and Dried Blood for HIV Infection in Infants," International Journal Of Biological and Medical Research, Vol. 3, No. 1, 2012, pp. 1369-1372.

[11] I. Beck, K. D. Drenna, A. J. Melvin, et al., "Simple, Sensitive, and Specific Detection of Human Immunodeficiency Virus Type 1 subtype B DNA in Dried Blood Samples for Diagnosis in Infants in the Field," Journal of Clinical Microbiology, Vol. 39, No. 1, 2001, pp. 29-33. doi:10.1128/JCM.39.1.29-33.2001

[12] UNAIDS-WHO Working Group on Global HIV/AIDS/ STI Surveillance, "Guidelines for Using HIV Testing Technologies in Surveillance," 2009.

[13] J. C. Plantier, R. Dachraoui, V. Lemée, M. Gueudin, F. Borsa-Lebas, F. Caron and F. Simon, "HIV-1 Resistance Genotyping on Dried Serum Spots," AIDS, Vol. 19, No. 4, 2005, pp. 391-397. doi:10.1097/01.aids.0000161768.98534.e7

[14] F. Barin, L. L. Meyer, R. Lancar, C. Deveau, M. Gharib, A. Laporte, J. C. Desenclos and D. Costagliola, "Development and Validation of an Immunoassay for Identification of Recent Human Immunodeficiency Virus Type 1 Infections and Its Use on Dried Serum Spots," Journal of Clinical Microbiology, Vol. 43, No. 9, 2005, pp. 44414447. doi:10.1128/JCM.43.9.4441-4447.2005

[15] R. Dachraoui, D. Brand, S. Brunet, F. Barin and J. C. Plantier, "RNA Amplification of the HIV-1pol and Env Regions on Dried Serum and Plasma Spots," HIV Medicine, Vol. 9, 2008, pp. 557-561. doi:10.1111/j.1468-1293.2008.00604.x

[16] R. L. Hamers, P. W. Smit, W. Stevens, R. Schuurman and T. F. Rinke de Wit, "Dried Fluid Spots for HIV Type 1 Viral Load and Resistance Genotyping: A Systematic Review," Antiviral Therapy, Vol. 14, 2009, pp. 619-629.

[17] R. Dachraoui, A. Depatureaux, M. Chakroun, et al., "Monitoring of HIV-1 Resistance in Tunisia (North Africa) with a Dried Plasma Spots Strategy," Journal of Acquired Immune Deficiency Syndromes, Vol. 47, No. 4, 2008, pp. 522-525. doi:10.1097/QAI.0b013e318166498a

[18] M. Monleau, C. Montavon, C. Laurent, M. Segondy, B. Montes, E. Delaporte, F. Boillot and M. Peeters, "Evaluation of Different RNA Extraction Methods and Storage Conditions of Dried Plasma and Blood Spots for Human Immunodeficiency Virus Type 1 RNA Quantification and PCR Amplification for Drug Resistance Testing," Journal of Clinical Microbiology, Vol. 47, No. 4, 2009, pp. 1107 1118. doi:10.1128/JCM.02255-08

[19] M. Andreotti, M. Pirillo, G. Guidotti, S. Ceffa, G. Paturzo, P. Germano, R. Luhanga, D. Chimwaza, M. G. Mancini, M. C. Marazzi, S. Vella, L. Palombi and M. Giuliano, "Correlation between HIV-1 Viral Load Quantification in Plasma, Dried Blood Spots and Dried Plasma Spots Using the Roche COBAS TaqMan Assay," Journal of Clinical Virology, Vol. 47, No. 1, 2010, pp. 4-7.

doi:10.1016/j.jcv.2009.11.006

[20] J. Dalmau, F. M. Codoner, I. Erkizia, M. Pino, C. Pou, R. Paredes, B. Clotet, J. Martinez-Picado and J. G. Prado, "In-Depth Characterization of Viral Isolates from Plasma and Cells Compared with Plasma Circulating Quasispecies in Early HIV-1 Infection," PloS ONE, Vol. 7, No. 2, 2012, Article ID: e32714.

doi:10.1371/journal.pone.0032714

[21] S. Reigadas, M. H. Schrive, Aurillac-Lavignolle and H. J. Fleury, "Quantification of HIV-1 RNA in Dried Blood and Plasma Spots," Journal of Virological Methods, Vol. 161, No. 1, 2009, pp. 177-180. doi:10.1016/i.jviromet.2009.06.002

[22] S. Masciotra, C. Garrido, A. S. Youngpairoj, A. McNulty, N. ZZahonero, A. Corral, W. Heneine, C. de Mendoza and J. G. Garcia-Lerma, "High Concordance between HIV-1 Drug Resistance Genotypes Generayed from Plasma and Dried Blood Spots in Antiretroviral-Experienced Patients," AIDS, Vol. 21, No. 18, 2007, pp. 2503-2511. doi:10.1097/QAD.0b013e3281c618db

[23] A. J. Buckton, S. L. Bissett, R. E. Myers, et al., "Development and optimization of an internally controlled dried blood assay for surveillance of human immunodeficiency virus type 1 drug resistance," Journal of Antimicrobial Chemotherapy, Vol. 62, No. 6, 2008, pp. 1191-1198. doi:10.1093/jac/dkn412

[24] S. Uttayamakul, S. Likanonsakul, R. Sunthornkachit, et al., "Usage of Dried Blood Spots for Molecular Diagnosis and MonitoringHIV-1 Infection," Journal of Virological Methods, Vol. 128, No. 1-2, 2005, pp. 128-134. doi:10.1016/i.jviromet.2005.04.010

[25] J. Garcia-Lerma, A. McNulty, C. Jennings, D. Huang, W. Heneine and J. Bremer, "Rapid Decline in the Efficiency of HIV Drug Resistance Genotyping from Dried Blood Spots (DBS) and Dried Plasma Spots (DPS) Stored at $37^{\circ} \mathrm{C}$ and High Humidity," Journal of Antimicrobial Chemotherapy, Vol. 64, No. 1, 2009, pp. 33-36. doi:10.1093/jac/dkp150

[26] S. Bertagnolio, L. Soto-Ramirez, R. Pilon, et al., "HIV-1 Drug Resistance Surveillance Using Dried Whole Blood Spots," Antiviral Therapy, Vol. 12, 2007, pp. 107-113.

[27] C. Wallis, C. Bell, P. Horsfield, T. Rinke de Wit and W. 
Stevens, “Affordable Resistance Test for Africa (ARTA): DBS Storage and Extraction Conditions for HIV Subtype C," The 5th International AIDS Society Conference on HIV Pathogenesis, Treatment and Prevention, Cape Town, 2009.

[28] C. Ziemniak, A. George-Agwu, W. Moss, S. Ray and D. Persaud (2006) Sensitive Genotyping Assay for Detection of Drug Resistance Mutations in Reverse Transcriptase of HIV-1 Subtypes B and C in Samples Stored as Dried Blood Spots or Frozen ARN Extracts," Journal of Virological Methods, Vol. 136, No. 1-2, 2006, pp. 238-247. doi:10.1016/j.jviromet.2006.05.030

[29] J. Nelson, A. Loftis, D. Kamwendo, et al., "Nevirapine Resistance in Human Immunodeficiency Virus Type 1-Positive Infants Determined Using Dried Blood Spots Stored for Up to 6 Years at Room Temperature," Journal of Clinical Microbiology, Vol. 447, No. 4, 2009, pp. 12091211. doi:10.1128/JCM.00254-09

[30] A. Youngpairoj, S. Masciotra, C. Garrido, N. Zahonero, C. de Mendoza and J. Garcia-Lerma, "HIV-1 Drug Resistance Genotyping from Dried Blood Spots Stored for 1 Year at $4{ }^{\circ} \mathrm{C}$," Journal of Antimicrobial Chemotherapy, Vol. 61, No. 6, 2008, pp. 1217-12120. doi: $10.1093 / \mathrm{jac} / \mathrm{dkn} 100$

[31] A. McNulty, C. Jennings, D. Bennett, et al., "Evaluation of Dried Blood Spots for Human Immunodeficiency Virus Type 1 Drug Resistance Testing," Journal of Clinical Microbiology, Vol. 45, No. 2, 2007, pp. 517-521. doi:10.1128/JCM.02016-06

[32] A. Hearps, C. Ryan, L. Morris, M. Plate, V. Greengrass and S. Crowe, "Stability of Dried Blood Spots for HIV-1 Drug Resistance Analysis," Current HIV Research, Vol. 8, No. 2, 2010, pp. 134-140. doi:10.2174/157016210790442740

[33] N. Metha, S. Trzmielina, B. A. S. Nonyane, M. N. Eliot, R. Lin, A. S. Foulkes, K. McNeal, A. Ammann, V. Eulalievyolo, J. L. Suliman, K. Luzuriaga and M. Somasundaran, "Low-Cost HIV-1 Diagnosis and Quantification in Dried Blood Spots by Real Time PCR," PLos ONE, Vol. 4, No. 6, 2009, Article ID: e5819. doi:10.1371/journal.pone.0005819

[34] P. Mwaba, S. Cassol, A. Nunn, et al., "Whole Blood Versus Plasma Spots for Measurment of HIV-1 Viral Load in HIV-Infected African Patients," Lancet, Vol. 362, No. 9401, 2003, pp. 2067-2068. doi:10.1016/S0140-6736(03)15103-3

[35] S. S. Solomon, S. Solomon, I. Rodriguez, et al., "Dried Blood Spots (DBS): A Valuable Tool for HIV Surveillance in Developing/Tropical Countries," International Journal of STD AIDS, Vol. 13, No. 1, 2002, pp. 25-28. doi:10.1258/0956462021924578

[36] G. Somi, T. Kibuka, K. K. Diallo, et al., "Surveillance of Transmitted HIV Drug Resistance among Women Attending Antenatal Clinics in Dar es Salaam, Tanzania," Antiviral Therapy, Vol. 13, Suppl. 2, 2008, pp. 77-82.

[37] W. Stevens, L. Scott and S. Crowe, "Quantifying HIV for Monitoring Antiretroviral Therapy in Resource-Poor Settings," The Journal of Infectious Diseases, Vol. 201, Suppl. 1, 2010, pp. S16-S26. doi:10.1086/650392
[38] L. Waters, A. Kambungu, H. Tibenderana, et al., "Evaluation of Filter Paper Transfer of Whole-Blood and Plasma Samples for Quantifying HIV RNA in Subjects on Antiretroviral Therapy in Uganda," Journal of Acquired Immune Deficiency Syndromes, Vol. 46, No. 5, 2007, pp. 590-593. doi:10.1097/QAI.0b013e318159d7f4

[39] A. Mbida, S. Soso, P. Flori, et al., "Measure of Viral Load by Using the Abbott Real-Time HIV-1 Assay on Dried Blood and Plasma Spots Specimens Collected in 2 Rural Dispensaries in Cameroon," Journal of Acquired Immune Deficiency Syndromes, Vol. 52, No. 1, 2009, pp. 9-16. doi:10.1097/QAI.0b013e3181aeccbc

[40] K. Kamoto and J. Aberie-Grasse, "Surveillance of Transmitted HIV Drug Resistance with the World Health Threshold Survey Method in Lilongwe, Malawi," Antiviral Therapy, Vol. 13, Suppl. 2, 2008, pp. 83-87.

[41] J. Zhang, D. Kang, J. Fu, et al., "Surveillance of Transmitted HIV Type 1 Drug Resistance in Newly Diagnosed HIV Type 1 Infected Patients in Shandong Province, China," AIDS Research and Human Retroviruses, Vol. 26, No. 1, 2010, pp. 99-103. doi:10.1089/aid.2009.0184

[42] U. Neogi, S. Gupta, R. Rodridges, P. N. Sahoo, S. D. Rao, B. B. Rewari, S. Shastri, A. De Costa and A. Shet, "Dried Blood Spot HIV-1 RNA Quantification: A Useful Tool for Viral Load Monitoring among HIV-Infected Individuals in India," The Indian Journal of Medical Research, Vol. 136, No. 6, 2012, pp. 956-962.

[43] R. Hallack, L. Doherty, J. Wethers and M. Parker, "Evaluation of Dried Blood Spot Specimens for HIV-1 Drug-Resistance Testing Using the Trugene HIV-1 Genotyping Assay," Journal of Clinical Virology, Vol. 41, No. 4, 2008, pp. 283-287. doi:10.1016/j.jcv.2007.12.011

[44] M. T. Alvarez-Munoz, S. Zaragoza-Rodriguez, O. RojasMontes, et al., "High Correlation of Human Immunodeficiency Virus Type 1 Viral Load Measured in Dried-Blood Spot Samples and Plasma under Different Storage Conditions," Archives of Medical Research, Vol. 36, No. 4, 2005, pp. 382-386. doi:10.1016/j.arcmed.2005.03.010

[45] W. Ayele, R. Schuurman, T. Messele, et al., "Use of Dried Spots of Whole Blood, Plasma, and Mother's Milk Collected on Filter Paper for Measurement of Human Immunodeficieny Virus type 1 Burden," Journal of Clinical Microbiology, Vol. 45, No. 3, 2007, pp. 891-896. doi:10.1128/JCM.01919-06

[46] C. T. Kane, H. D. Ndiaye, S. Diallo, et al., "Quantification of HIV-1 RNA in Dried Blood Spots by Real-Time NucliSENS EasyQ HIV-1 Assay in Senegal," Journal of Virological Methods, Vol. 148, No. 1-2, 2008, pp. 291295. doi:10.1016/j.jviromet.2007.11.011

[47] B. Amellal, C. Katlama and V. Calvez, "Evaluation of the Use of Dried Spots and of Different Storage Conditions of Plasma for HIV-1 RNA Quantification," HIV Medicine, Vol. 8, No. 6, 2007, pp. 396-400. doi:10.1111/j.1468-1293.2007.00484.x

[48] M. C. Knuchel, Z. Tomasik, R. F. Speck, R. Luthy and J. Schupbach, "Ultrasensitive Quantitative HIV-1 p24 Antigen Assay Adapted to Dried Plasma Spots to Improve Treatment Monitoring in Low-Resource Setting," Journal of Clinical Virology, Vol. 36, No. 1, 2006, pp. 64-67. 
doi:10.1016/j.jcv.2005.12.005

[49] C. Garrido, N. Zahonero, D. Fernades, et al., "Subtype Variability, Virological Response and Drug Resistance Assessed on Dried Blood Spots Collected from HIV Patients on Antiretroviral Therapy in Angola," Journal of Antimicrobial Chemotherapy, Vol. 61, No. 3, 2008, pp. 694-698. doi:10.1093/jac/dkm515

[50] R. Lira, H. Valdez-Salazar, G. Vazquez-Rosales, et al., "Genotypic Testing for HIV-1 Drug Resistance Using Dried Blood Samples," Archives of Virology, Vol. 155, No. 7, 2010, pp. 1117-1125. doi:10.1007/s00705-010-0696-y

[51] X. Bi, H. Gatanaga, S. Ida, et al., "Emergence of Protease Inhibitor Resistance-Associated Mutations in Plasma HIV-1 Precedes that in Provirus of Peripheral Blood
Mononuclear Cells by More than a Year," Journal of Acquired Immune Deficiency Syndromes, Vol. 34, No. 1, 2003, pp. 1-6. doi:10.1097/00126334-200309010-00001

[52] C. Chew, S. Potter, B. Wang, et al., "Assessment of Drug Resistance Mutations in Plasma and Peripheral Blood Mononuclear Cells at Different Plasma Viral Loads in Patients Receiving HAART," Journal of Clinical Virology, Vol. 33, No. 3, 2005, pp. 206-216. doi:10.1016/j.jcv.2004.11.006

[53] A. Johannessen, C. Garrido, N. Zahonero, et al., "HIV-1 Drug Resistance Testing from Dried Blood Spots Collected in Rural Tanzania Using the ViroSeq HIV-1 Genotyping System," Journal of Antimicrobial Chemotherapy, Vol. 66, No. 2, 2011, pp. 260-264. doi: $10.1093 / \mathrm{jac} / \mathrm{dkq} 433$ 